\title{
Development of an In-Situ Composite Doped Coating for Corrosion Protection and Mechanical Properties Enhancements in Process Engineering
}

\author{
Oluwasegun T. Joshua' ${ }^{1}$, Ojo S. I. Fayomi ${ }^{2 *}$, Enejoh T. Omeje ${ }^{3}$ \\ ${ }^{1}$ Department of Metallurgical \& Materials Engineering, Kogi State Polytechnic, Lokoja, Nigeria \\ ${ }^{2}$ Department of Mechanical Engineering, Covenant University, Ota, Nigeria \\ ${ }^{3}$ Department of Mineral Resource Engineering, Kogi State Polytechnic, Lokoja, Nigeria \\ Email: ^Ojosundayfayomi3@gmail.com, *segetin80@yahoo.com
}

How to cite this paper: Joshua, O.T., Fayomi, O.S.I. and Omeje, E.T. (2019) Development of an In-Situ Composite Doped Coating for Corrosion Protection and Mechanical Properties Enhancements in Process Engineering. Journal of Minerals and Materials Characterization and Engineering, 7, 171-179.

https://doi.org/10.4236/jmmce.2019.74013

Received: May 6, 2019

Accepted: July 20, 2019

Published: July 23, 2019

Copyright $\odot 2019$ by author(s) and Scientific Research Publishing Inc. This work is licensed under the Creative Commons Attribution International License (CC BY 4.0).

http://creativecommons.org/licenses/by/4.0/

\begin{abstract}
Process engineering has been seen as one of the vital tools for improving surface coating phenomena for advance application. In an attempt to improve the mechanical, physical and chemical performance of the steel structure for extended application, $\mathrm{Zn}-\mathrm{CeO}_{2} / \mathrm{ZnCeO}_{2}-\mathrm{Al}_{2} \mathrm{SiO}_{5}$ thin film composite was fabricated on mild steel using direct electrolytic route. Process variation of $\mathrm{Al}_{2} \mathrm{SiO}_{5}$ particulate ranges from 5 to $15 \mathrm{~g}$ per litre. The embedded coating was characterized using Scanning electron microscope (SEM). The chemical effect of the developed alloy was characterized through linear potentiodynamic polarization experiment and the performances of samples were examined in simulated $3.5 \%$ sodium chloride. The microhardness verification study proves that there is significant improvement in hardness trend. The tribological assessment indicated that there is less plastic deformation as a result of the counter body. In all, $\mathrm{Zn}-\mathrm{CeO}_{2} / \mathrm{Zn}-\mathrm{CeO}_{2}-\mathrm{Al}_{2} \mathrm{SiO}_{5}$ exhibits good stability, with agglomeration and great built up of crystal at the interface.
\end{abstract}

\section{Keywords}

Coating, Mild Steel, Corrosion, Hardness

\section{Introduction}

Corrosion is an unwanted phenomenon that destroys the lustre and aesthetics of objects and drastically decreases their lifespan. Corrosion is destructive and detrimental to structural, equipment and component failure [1]. The unrelenting 
effects of corrosion attack have become a global topic for consideration. Corrosion effect is undesirable causing physical and chemical changes in the property of steel it has attacked [2]. The result of studies in a number of countries in relation to corrosion has attempted to determine the national cost of corrosion. The most comprehensive of these studies was carried out in the United States in 1976 and determined that the total yearly cost of metallic corrosion on the economy was estimated high. Corrosion is still a major problem and slows down the advancement and application of such alloys due to failures which reduce the useful life of the prosthetic and cause more harm in the human body [3] [4].

Electrochemical corrosion occurs when a metal atom changes to a metal ion by the loss of electrons. This is because of the presence of cathodic and anodic areas on a metal surface which reacts with air and moisture in the surroundings. The heterogeneous and impure nature of metals contributes largely to their poor corrosion resistance [5] [6]. Corrosion can be controlled through a range of methods which have varying degrees of success. The methods include the use of inhibitors, coating, protective treatments and the utilization of better designs for structures and equipment, understanding the mechanisms of various forms of corrosion and using materials with high corrosion resistance [7]. This present research examined the performance of mild steel coated $\mathrm{Zn}-\mathrm{CeO}_{2} / \mathrm{Zn}-\mathrm{CeO}_{2}-\mathrm{Al}_{2} \mathrm{SiO}_{5}$ in a simulated sodium chloride environment. The morphologies of the test samples were studied using SEM while the hardness and wear test was carried out using the Brinell hardness tester and reciprocating wear testing machine.

\section{Experimental Procedure}

\subsection{Preparation of Substrate}

The composition of mild steel used in this study is shown in Table 1. Mild steel of dimension $(30 \mathrm{~mm} \times 20 \mathrm{~mm} \times 2 \mathrm{~mm})$ and zinc sheets of $(50 \mathrm{~mm} \times 20 \mathrm{~mm} \times$ $5 \mathrm{~mm}$ ) were prepared. The zinc is commercially available pure zinc (99.99\%). Mild steel was polished with different grades of emery papers.

\subsection{Bath Formulation}

The prepared bath composition with optimized mass concentration is shown in Table 2. The essence of this was to create novel composite plating on mild steel using composite particulates of zinc, aluminium silicate $\left(\mathrm{Al}_{2} \mathrm{SiO}_{5}\right)$, cerium (iv) oxide $\left(\mathrm{CeO}_{2}\right)$ in varying proportions with the aim of determining the most effective coating.

\subsection{Deposition of $\mathrm{Zn}-\mathrm{CeO}_{2} / \mathrm{Zn}-\mathrm{CeO}_{2}-\mathrm{Al}_{2} \mathrm{SiO}_{5}$}

For the pre-plating process, the surface of the samples was prepared using

Table 1. Chemical composition of mild steel sample (\%wt).

\begin{tabular}{ccccccccc}
\hline Elements & $\mathrm{C}$ & $\mathrm{Mn}$ & $\mathrm{Si}$ & $\mathrm{P}$ & $\mathrm{Al}$ & $\mathrm{S}$ & $\mathrm{Ni}$ & $\mathrm{Fe}$ \\
\hline $\mathrm{Wt} \%$ & 0.15 & 0.45 & 0.18 & 0.01 & 0.005 & 0.031 & 0.008 & Balance \\
\hline
\end{tabular}


Table 2. Bath concentration and formulation.

\begin{tabular}{cc}
\hline COMPOSITION & MASS CONCENTRATION \\
\hline Zinc Chloride & $70 \mathrm{~g} / \mathrm{L}$ \\
Cerium (iv) oxide & $10 \mathrm{~g} / \mathrm{L}$ \\
Boric Acid & 5 \\
Glycerin & $5 \mathrm{~g} / \mathrm{L}$ \\
Aluminum silicate & $0-15 \mathrm{~g}$ \\
pH & 4.5 \\
Temp. & $50^{\circ} \mathrm{C}$ \\
Time & $10 \mathrm{mins}$ \\
Current Intensity & $1.5 \mathrm{~A} / \mathrm{cm}{ }^{2}$ \\
Thiourea & $5 \mathrm{~g} / \mathrm{L}$ \\
Sodium Sulphate & $5 \mathrm{~g} / \mathrm{L}$ \\
Potassium Sulphate & $5 \mathrm{~g} / \mathrm{L}$ \\
\hline
\end{tabular}

different grades of emery paper in order of $60 \mu \mathrm{m}, 120 \mu \mathrm{m}, 360 \mu \mathrm{m}, 400 \mu \mathrm{m}$ and $1600 \mu \mathrm{m}$ grades. Water was used as coolant to avoid burning out of the samples. The pickling of the samples was done in diluted $10 \% \mathrm{HCl}$ acid solution; this was to remove all organic contaminants and oxides. In the plating process, the metal substrate was immersed in a solution containing the dissolved powders of the metals to be deposited. The working substrate (mild steel cathode) was connected to the negative terminal of the rectifier. The zinc anode was also immersed and connected to the positive terminal of the rectifier as shown in Figure 1 . The $\mathrm{pH}$ used was 4.5 , other plating parameters such as current density; voltage and time were kept at $1.5 \mathrm{~A} / \mathrm{cm}^{2}, 2.0 \mathrm{~V}$ and 10 minutes respectively as indicated in Table 3 . The coatings of the samples were carried out in accordance to ASTM A53/A53M and A153 [8]. Finally, the plated samples were rinsed in distilled water to wash off the salt solution immediately after the electroplating process then air dried. Thereafter, series of characterizations such as the study of morphology via SEM, electrochemical using potentiodynamic polarization experiment, Brinell hardness and wear tester were employed to study the performance of the deposited coatings on the substrate.

\section{Results and Discussion}

\subsection{SEM of Deposited Composite Coating}

The SEM structure of $\mathrm{Zn}-10 \mathrm{CeO}_{2}, \mathrm{Zn}-10 \mathrm{CeO}_{2}-5 \mathrm{Al}_{2} \mathrm{SiO}_{5}, \mathrm{Zn}-10 \mathrm{CeO}_{2}-10 \mathrm{Al}_{2} \mathrm{SiO}_{5}$ and $\mathrm{Zn}-10 \mathrm{CeO}_{2}-15 \mathrm{Al}_{2} \mathrm{SiO}_{5}$ coated mild steel is shown in Figures $2-5$ respectively. The figures show visible crystallites and homogenously distributed of the particles on the steel. Figure 4 shows visible integration crystallite of $\mathrm{CeO}_{2}$ nanoparticulates. Figures 3-5 unveiled to phase due to the integration of $\mathrm{CeO}_{2}$ and $\mathrm{Al}_{2} \mathrm{SiO}_{5}$ in the zinc interface which increases as the mass concentration of 


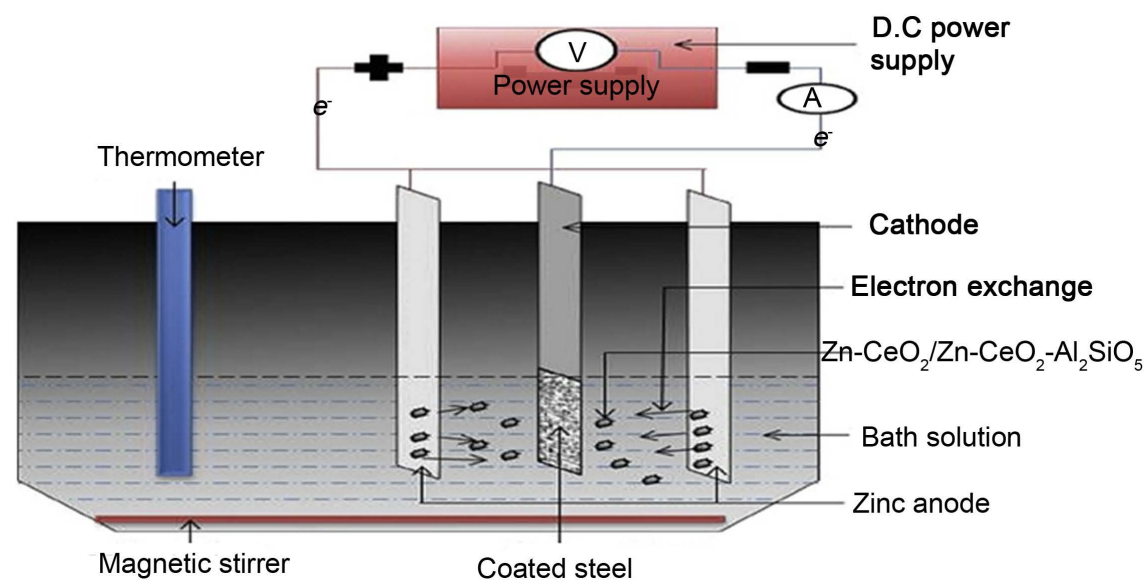

Figure 1. Schematic diagram of a co-deposition system.

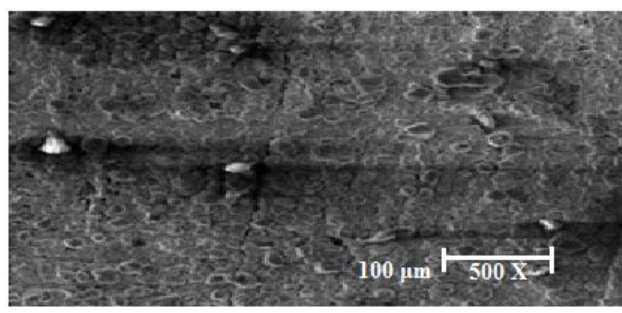

Figure 2. SEM structure of $\mathrm{Zn}-10 \mathrm{CeO}_{2}$ coated steel.

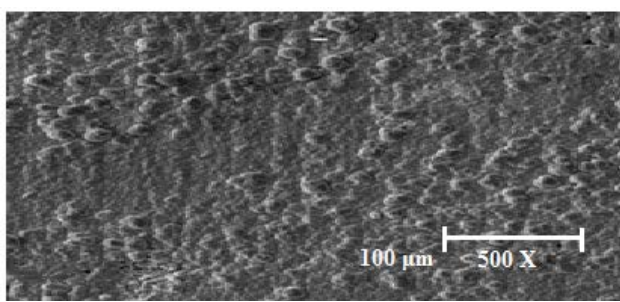

Figure 3. SEM structure of $\mathrm{Zn}-10 \mathrm{CeO}_{2}-5 \mathrm{Al}_{2} \mathrm{SiO}_{5}$ coated steel.

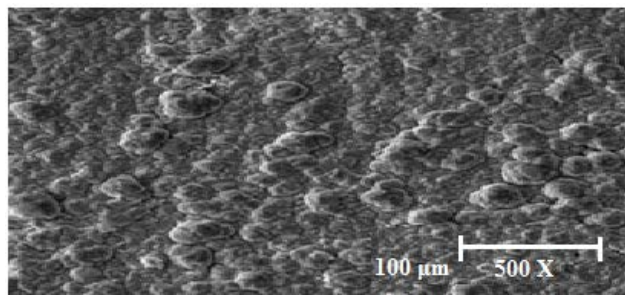

Figure 4. SEM structure of $\mathrm{Zn}-10 \mathrm{CeO}_{2}-10 \mathrm{Al}_{2} \mathrm{SiO}_{5}$ coated steel.

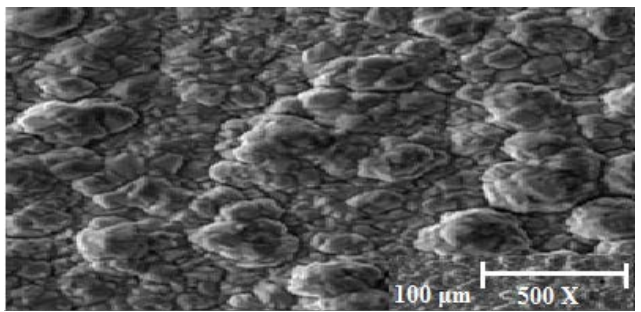

Figure 5. SEM structure of $\mathrm{Zn}-10 \mathrm{CeO}_{2}-15 \mathrm{Al}_{2} \mathrm{SiO}_{5}$. coated steel. 
Table 3. Electrodeposition parameters of $\mathrm{Zn}-\mathrm{CeO}_{2} / \mathrm{Zn}-\mathrm{CeO}_{2}-\mathrm{Al}_{2} \mathrm{SiO}_{5}$ mild steel.

\begin{tabular}{ccccc}
\hline Sample & Time $(\mathrm{min})$ & Voltage & $\mathrm{pH}$ & Current Density $\left(\mathrm{A} / \mathrm{cm}^{2}\right)$ \\
\hline $\mathrm{Zn}-10 \mathrm{CeO}_{2}$ & 10 & 2 & 4.5 & 1.5 \\
$\mathrm{Zn}-10 \mathrm{CeO}_{2}-5 \mathrm{Al}_{2} \mathrm{SiO}_{5}$ & 10 & 2 & 4.5 & 1.5 \\
$\mathrm{Zn}-10 \mathrm{CeO}_{2}-10 \mathrm{Al}_{2} \mathrm{SiO}_{5}$ & 10 & 2 & 4.5 & 1.5 \\
$\mathrm{Zn}-10 \mathrm{CeO}_{2}-15 \mathrm{Al}_{2} \mathrm{SiO}_{5}$ & 10 & 2 & 4.5 & 1.5 \\
\hline
\end{tabular}

$\mathrm{Al}_{2} \mathrm{SiO}_{5}$ increases. The synergistic and complementary effect of $\mathrm{CeO}_{2}$ and $\mathrm{Al}_{2} \mathrm{SiO}_{5}$ on the coating surface and the interface is responsible for the refined morphology of the coated samples due to the load carrying ability of zinc metal which acts as the nucleation domains and therefore enhancing the formation of the nanocomposites [9] [10] [11] [12].

More so, the slight change in the structure of Figures 3-5 compared to Figure 2 could be as a result of $\mathrm{Al}_{2} \mathrm{SiO}_{5}$ inclusion in the matrix of the nanocomposite which results in the precipitation and enhanced reinforcement [13]. One can therefore conclude that the porosity of the composite coatings reduces with the incorporation of $\mathrm{Al}_{2} \mathrm{SiO}_{5}$ particles in the coating. This is in accordance to the finding of other authors [11] [14].

\subsection{Electrochemical Test Result}

The values of corrosion current density (Icorr), corrosion potential (Ecorr), corrosion rate $(\mathrm{CR})$ and polarization resistance $\left(\mathrm{R}_{\mathrm{P}}\right)$ of the coated and uncoated samples in $3.5 \% \mathrm{NaCl}$ were obtained from the extrapolation of Tafel plot shown in Figure 6. The results reveal the corrosion resisting characteristics of the particles in the test solution. $\mathrm{Zn}-\mathrm{CeO}_{2} / \mathrm{Zn}-\mathrm{CeO}_{2}-\mathrm{Al}_{2} \mathrm{SiO}_{5}$ was able to block the active sites of the metals from corroding [15] [16]. Corrosion rate of $\mathrm{Zn}-10 \mathrm{CeO}_{2}-5 \mathrm{Al}_{2} \mathrm{SiO}_{5}$ coated sample was the lowest when compared with others as indicated in Table 4. This could traceable to the nature and tenacity of the passive film produced by $\mathrm{Zn}-10 \mathrm{CeO}_{2}-5 \mathrm{Al}_{2} \mathrm{SiO}_{5}$ on the surface of the coated steel or chemical stability of the samples [17].

\subsection{Microhardness Behaviour of $\mathrm{Zn}-\mathrm{CeO}_{2} / \mathrm{Zn}-\mathrm{CeO}_{2}-\mathrm{Al}_{2} \mathrm{SiO}_{5}$ Deposition}

Figure 7 shows the mircohardness of the test samples. $\mathrm{Zn}-10 \mathrm{CeO}_{2}-10 \mathrm{Al}_{2} \mathrm{SiO}$ coated steel has the highest Brinell hardness value of 203 BHN for the electrodeposited sample. Generally, the coated samples exhibit higher value of hardness compared to the uncoated sample which could be attributed to the strain energy between the particles and the steel [18] [19] (Table 5).

\subsection{Wear Behaviour of $\mathrm{Zn}-\mathrm{CeO}_{2} / \mathrm{Zn}-\mathrm{CeO}_{2}-\mathrm{Al}_{2} \mathrm{SiO}_{5}$ Deposition}

The wear behaviour of the uncoated and coated samples is shown in Figure 8. The uncoated sample exhibits the highest value of wear loss compared to the coated samples. The uncoated sample has a wear loss of $0.019 \mathrm{~g} / \mathrm{min}$ while the 


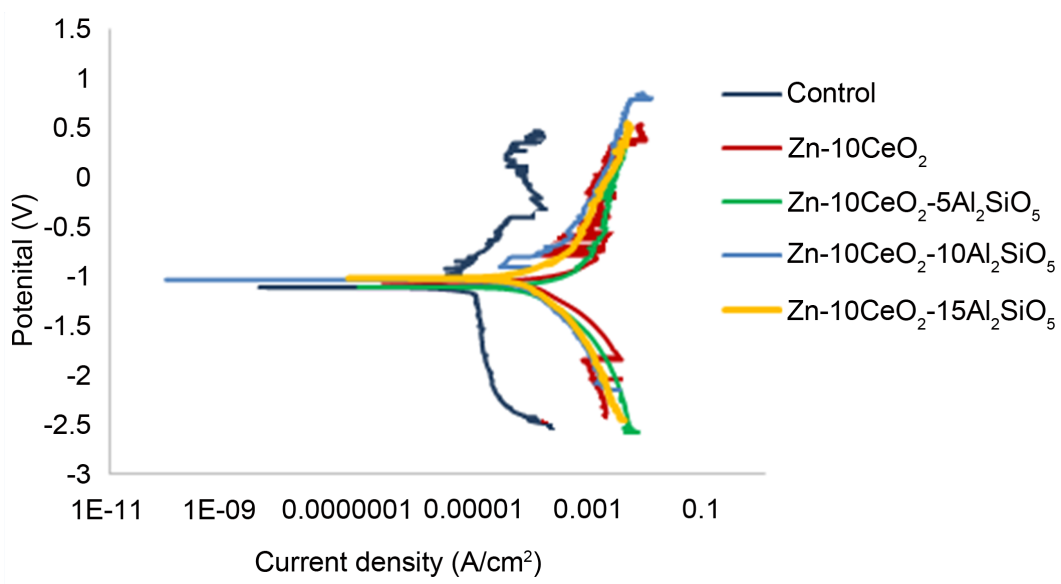

Figure 6. Potentiodynamic polarization Curves of $\mathrm{Zn}-\mathrm{CeO}_{2} / \mathrm{Zn}-\mathrm{CeO}_{2}-\mathrm{Al}_{2} \mathrm{SiO}_{5}$ coated and uncoated samples.

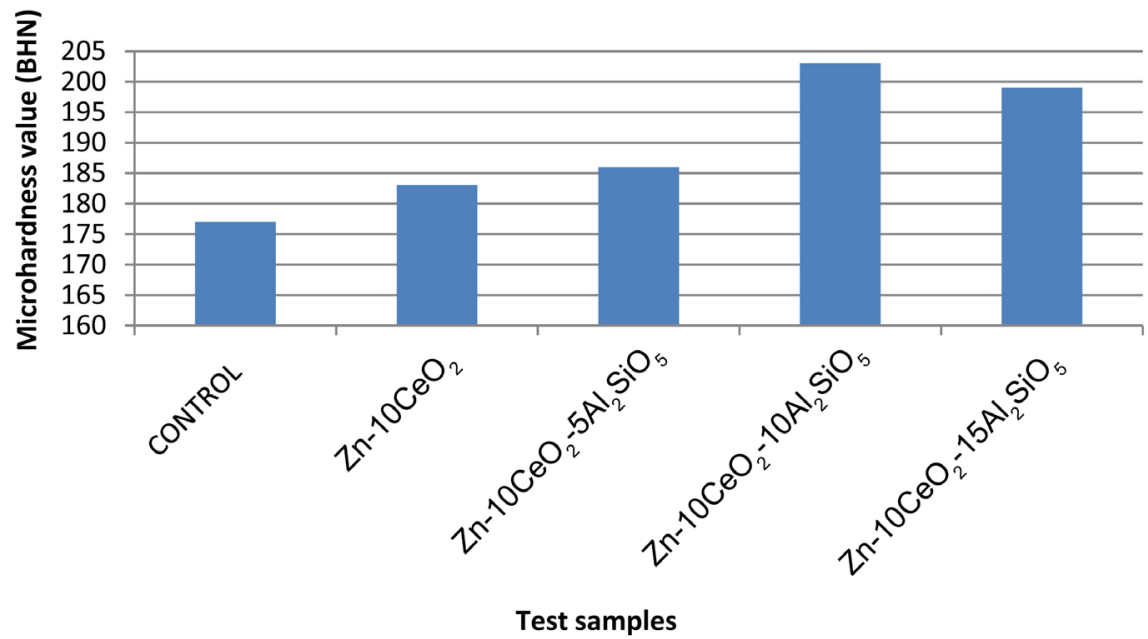

Figure 7. Brinell hardness value for $\mathrm{Zn}-\mathrm{CeO}_{2} / \mathrm{Zn}-\mathrm{CeO}_{2}-\mathrm{Al}_{2} \mathrm{SiO}_{5}$ deposition.

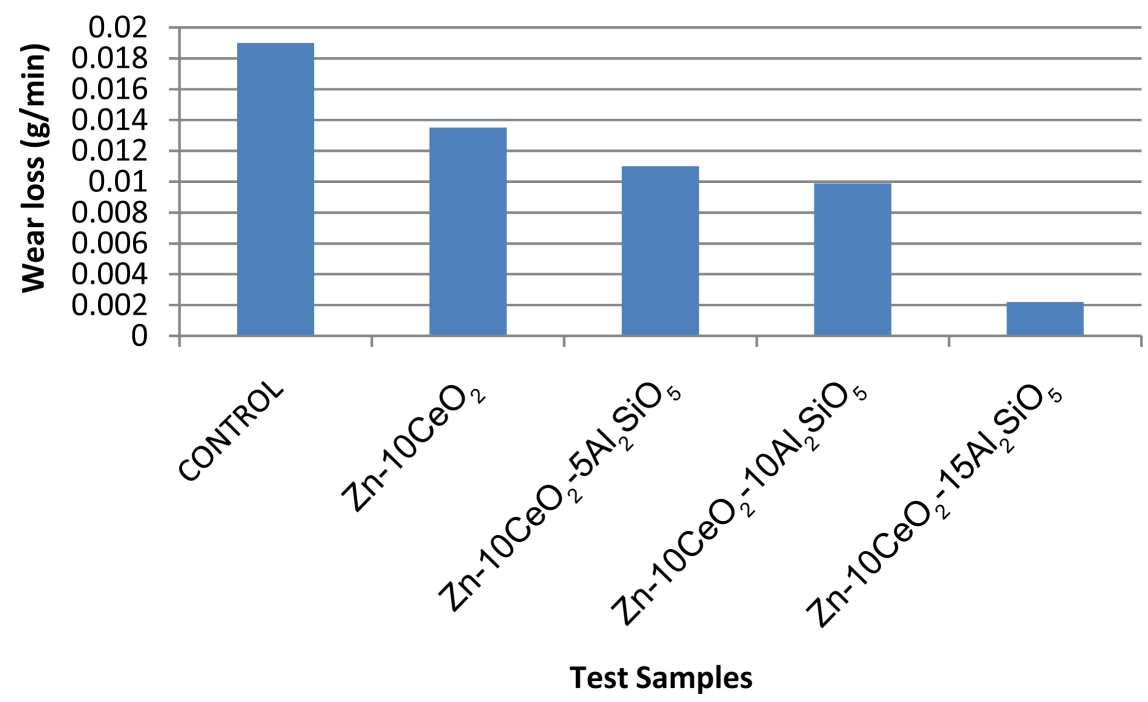

Figure 8. Wear behaviour of $\mathrm{Zn}-\mathrm{CeO}_{2} / \mathrm{Zn}-\mathrm{CeO}_{2}-\mathrm{Al}_{2} \mathrm{SiO}_{5}$ deposition. 
$\mathrm{Zn}-10 \mathrm{CeO}_{2}-15 \mathrm{Al}_{2} \mathrm{SiO}_{5}$ coated sample has the lowest wear loss vale of 0.001 $\mathrm{g} / \mathrm{min}$. This could be attributed to coherence interaction between the steel and the coating and the processing parameters [18] [20] [21]. The $\mathrm{Zn}-10 \mathrm{CeO}_{2}-10 \mathrm{Al}_{2} \mathrm{SiO}_{5}$ and $\mathrm{Zn}-10 \mathrm{CeO}_{2}-15 \mathrm{Al}_{2} \mathrm{SiO}_{5}$ displays lower wear loss which justifies the higher hardness values they possess. This also indicates these samples possess higher strain energy that exists between the coating and the metal interface (Table 6).

\section{Conclusion}

The inclusion of the $\mathrm{CeO}_{2} / \mathrm{Al}_{2} \mathrm{SiO}_{5}$ particles in the zinc matrix improved the structural properties and proper dispersion of the particles. The electrochemical result showed that $\mathrm{Zn}-\mathrm{CeO}_{2} / \mathrm{Zn}-\mathrm{CeO}_{2}-\mathrm{Al}_{2} \mathrm{SiO}_{5}$ nano composite exhibited good corrosion resistance in $3.5 \% \mathrm{NaCl}$. The coated samples were also found to exhibit better microhardness and wear properties compared to the uncoated samples which are an indication that the steels mechanical characteristics have been influenced.

Table 4. Potentiodynamic polarization data of $\mathrm{Zn}-\mathrm{CeO}_{2} / \mathrm{Zn}-\mathrm{CeO}_{2}-\mathrm{Al}_{2} \mathrm{SiO}_{5}$ coated and uncoated samples.

\begin{tabular}{ccccc}
\hline Sample & Icorr $\left(\mathrm{A} / \mathrm{cm}^{2}\right)$ & $\mathrm{R}_{\mathrm{p}}(\Omega)$ & Ecorr $(\mathrm{V})$ & Corrosion rate $(\mathrm{mm} / \mathrm{yr})$ \\
\hline Control & $2.04 \mathrm{E}-4$ & 198 & -1.2122 & 2.57 \\
$\mathrm{Zn}-10 \mathrm{CeO}_{2}$ & $3.38 \mathrm{E}-07$ & 3184 & -1.0942 & 0.0254 \\
$\mathrm{Zn}-10 \mathrm{CeO}_{2}-5 \mathrm{Al}_{2} \mathrm{SiO}_{5}$ & $1.47 \mathrm{E}-07$ & 4050 & -1.0660 & 0.0171 \\
$\mathrm{Zn}-10 \mathrm{CeO}_{2}-10 \mathrm{Al}_{2} \mathrm{SiO}_{5}$ & $3.853 \mathrm{E}-06$ & 1890 & -1.0969 & 0.0445 \\
$\mathrm{Zn}-10 \mathrm{CeO}_{2}-15 \mathrm{Al}_{2} \mathrm{SiO} 5$ & $2.19 \mathrm{E}-06$ & 2197 & -1.1086 & 0.0439 \\
\hline
\end{tabular}

Table 5. Microhardness behaviour of $\mathrm{Zn}-\mathrm{CeO}_{2} / \mathrm{Zn}-\mathrm{CeO}_{2}-\mathrm{Al}_{2} \mathrm{SiO}_{5}$ coated and uncoated samples.

\begin{tabular}{cc}
\hline Test Samples & Microhardness values (BHN) \\
\hline Control & 177 \\
$\mathrm{Zn}-10 \mathrm{CeO}_{2}$ & 183 \\
$\mathrm{Zn}-10 \mathrm{CeO}_{2}-5 \mathrm{Al}_{2} \mathrm{SiO}_{5}$ & 186 \\
$\mathrm{Zn}-10 \mathrm{CeO}_{2}-10 \mathrm{Al}_{2} \mathrm{SiO}_{5}$ & 203 \\
$\mathrm{Zn}-10 \mathrm{CeO}_{2}-15 \mathrm{Al}_{2} \mathrm{SiO}$ & 199 \\
\hline
\end{tabular}

Table 6. Wear loss behavior of $\mathrm{Zn}-\mathrm{CeO}_{2} / \mathrm{Zn}-\mathrm{CeO}_{2}-\mathrm{Al}_{2} \mathrm{SiO}_{5}$ coated and uncoated samples.

\begin{tabular}{cc}
\hline Test Samples & Wear loss $(\mathrm{g} / \mathrm{min})$ \\
\hline $\mathrm{Control}$ & 0.019 \\
$\mathrm{Zn}-10 \mathrm{CeO}_{2}$ & 0.0135 \\
$\mathrm{Zn}-10 \mathrm{CeO}_{2}-5 \mathrm{Al}_{2} \mathrm{SiO}_{5}$ & 0.011 \\
$\mathrm{Zn}-10 \mathrm{CeO}_{2}-10 \mathrm{Al}_{2} \mathrm{SiO}_{5}$ & 0.0099 \\
$\mathrm{Zn}-10 \mathrm{CeO}_{2}-15 \mathrm{Al}_{2} \mathrm{SiO} 5$ & 0.0022 \\
\hline
\end{tabular}




\section{Acknowledgements}

The authors of this article sincerely appreciate the management of Tertiary Education Trust Fund (TET fund) Nigeria for sponsoring this research and to the management of Kogi State Polytechnic, Lokoja Nigeria for their support.

\section{Conflicts of Interest}

The authors declare no conflicts of interest regarding the publication of this paper.

\section{References}

[1] Lee, Y.S., Heo, J., Siah, S.C., Mailoa, J.P., Brandt, R.E., Kim, S.B., Gordon, R.G. and Buonassisi, T. (2013) Ultrathin Amorphous Zinc-Tin-Oxide Buffer Layer for Enhancing Heterojunction Interface Quality in Metal-Oxide Solar Cells. Energy \& Environmental Science, 7, 2112-2118. https://doi.org/10.1039/c3ee24461j

[2] Renuka, N.K. (2012) Structural Characteristics of Quantum-Size Ceria Nano Particles Synthesized via Simple Ammonia Precipitation. Journal of Alloys and Compounds, 513, 230-235. https://doi.org/10.1016/j.jallcom.2011.10.027

[3] Fayomi, O.S.I. and Popoola, A.P.I. (2015) Development of Smart Oxidation and Corrosion Resistance of Multi-Doped Complex Hybrid Coatings on Mild Steel. Journal of Alloys and Compounds, 637, 382-392. https://doi.org/10.1016/j.jallcom.2015.02.154

[4] Bankole, M.T., Abdulkareem, A.S., Tijani, J.O., Ochigbo, S.S., Afolabi, A.S. and Roos, W.D. (2017) Chemical Oxygen Demand Removal from Electroplating Wastewater by Purified and Polymer Functionalized Carbon Nanotubes Adsorbents. Water Resources and Industry, 18, 33-50. https://doi.org/10.1016/j.wri.2017.07.001

[5] Winkler, D.A., Breedon, M., White, P., Hughes, A.E., Sapper, E.D. and Cole, I. (2016) Using High Throughput Experimental Data and in Silicon Models to Discover Alternatives to Toxic Chromate Corrosion Inhibitors. Corrosion Science, 106, 229-235. https://doi.org/10.1016/j.corsci.2016.02.008

[6] Aigbodion, V.S. and Fayomi, O.S.I. (2016) Anti-Corrosion Coating of Mild Steel Using Ternary Zn-ZnO- $\mathrm{Y}_{2} \mathrm{O}_{3}$ Electro-Deposition. Surface and Coatings Technolo$g y, 306,448-454$. https://doi.org/10.1016/j.surfcoat.2016.05.018

[7] Moreira, R.R., Soares, T.F. and Ribeiro, J. (2014) Electrochemical Investigation of Corrosion on AISI 316 Stainless Steel and AISI 1010 Carbon Steel: Study of the Behaviour of Imidazole and Benzimidazole as Corrosion Inhibitors. Advances in Chemical Engineering and Science, 4, 503. https://doi.org/10.4236/aces.2014.44052

[8] Toro, R.G., Malandrino, G., Fragalà, I.L., Lo Nigro, R., Losurdo, M. and Bruno, G. (2004) Relationship between the Nanostructures and the Optical Properties of $\mathrm{CeO}_{2}$ Thin Films. The Journal of Physical Chemistry B, 42, 16357-16364. https://doi.org/10.1021/jp048083j

[9] Fayomi, O.S.I. and Aigbodion, V.S. (2014) Effect of Thermal Treatment on the Interfacial Reaction, Microstructural and Mechanical Properties of $\mathrm{Zn}-\mathrm{Al}-\mathrm{SnO}_{2} / \mathrm{TiO}_{2}$ Functional Coating Alloys. Journal of Alloys and Compounds, 617, 455-463. https://doi.org/10.1016/j.jallcom.2014.07.141

[10] Oluyori, T., Olorunniwo, O.E., Fayomi, O.S. and Atanda, P.O. (2017) Performance Evaluation Effect of $\mathrm{Nb}_{2} \mathrm{O}_{5}$ Particulate on the Microstructural, Wear and An- 
ti-Corrosion Resistance of $\mathrm{Zn}-\mathrm{Nb}_{2} \mathrm{O}_{5}$ Coatings on Mild Steel for Marine Application. Journal of Bio- and Tribo-Corrosion, 4, 51. https://doi.org/10.1007/s40735-017-0108-x

[11] Alhawari, K.S., Omar, M.Z., Ghazali, M.J., Salleh, M.S. and Mohammed, M.N. (2013) Wear Properties of $\mathrm{A} 356 / \mathrm{Al}_{2} \mathrm{O}_{3}$ Metal Matrix Composites Produced by Semisolid Processing. Procedia Engineering, 68, 186-192.

https://doi.org/10.1016/j.proeng.2013.12.166

[12] Ahmed, I., Ahmad, Z., Patel, F. and Khan, M.S. (2011) A Photo-Cathodic Protection System Utilizing UV Radiations. International Journal of Engineering and Technology, 1, 197-202.

[13] Subasri, R., Shinohara, T. and Mori, K. (2005) Modified $\mathrm{TiO}_{2}$ Coatings for Cathodic Protection Applications. Science and Technology of Advanced Materials, 5, 501. https://doi.org/10.1016/j.stam.2005.01.003

[14] Akarapu, A. (2011) Surface Property Modification of Copper by Nanocomposite Coating. M. Tech. Thesis, Department of Metallurgical and Materials Engineering, National Institute of Technology, Rourkela.

[15] Dutta, A., Saha, S.K., Adhikari, U., Banerjee, P. and Sukul, D. (2017) Effect of Substitution on Corrosion Inhibition Properties of 2-(substituted phenyl) Benzimidazole Derivatives on Mild Steel in $1 \mathrm{M} \mathrm{HCl}$ Solution: A Combined Experimental and Theoretical Approach. Corrosion Science, 123, 256-266. https://doi.org/10.1016/j.corsci.2017.04.017

[16] Rossrucker, L., Samaniego, A., Grote, J.P., Mingers, A.M., Laska, C.A., Birbilis, N., Frankel, G.S. and Mayrhofer, K.J. (2015) The pH Dependence of Magnesium Dissolution and Hydrogen Evolution during Anodic Polarization. Journal of the Electrochemical Society, 7, 333-339. https://doi.org/10.1149/2.0621507jes

[17] Popoola, A.P.I., Daniyan, A.A., Umoru, L.E. and Fayomi, O.S.I. (2017) Effect of $\mathrm{WO}_{3}$ Nanoparticles Loading on the Microstructural, Mechanical and Corrosion Resistance of $\mathrm{Zn}$ Matrix/ $\mathrm{TiO}_{2}-\mathrm{WO}_{3}$ Nanocomposite Coatings for Marine Application. Journal of Marine Science and Application, 16, 1389. https://doi.org/10.1007/s11804-017-1389-7

[18] Rusu, D.E., Ispas, A., Bund, A., Gheorghies, C. and Carac, G. (2012) Corrosion Tests of Nickel Coatings Prepared from a Watts-Type Bath. Journal of Coatings Technology and Research, 1, 87-95. https://doi.org/10.1007/s11998-011-9343-0

[19] Agbo, P.E. and Nnabuchi, M.N. (2011) Core-Shell $\mathrm{TiO}_{2} / \mathrm{ZnO}$ Thin Film: Preparation, Characterization and Effect of Temperature on Some Selected Properties. Chalcogenide Letters, 8, 4.

[20] Fustes, J., Gomes, A. and da Silva Pereira, M.I. (2008) Electrodeposition of $\mathrm{Zn}-\mathrm{TiO}_{2}$ Nanocomposite Films-Effect of Bath Composition. Journal of Solid State Electrochemistry, 11, 1435-1443. https://doi.org/10.1007/s10008-007-0485-Z

[21] Okada, M., Tajima, K., Yamada, Y. and Yoshimura, K. (2008) Photocatalytic Performance of Very Thin $\mathrm{TiO}_{2} / \mathrm{SnO}_{2}$ Stacked-Film Prepared by Magnetron Sputtering. Vacuum, 3, 688-690. https://doi.org/10.1016/j.vacuum.2008.04.050 